\title{
The development of leadership through islamic education: An empirical inquiry into religiosity and the styles of educational leadership experienced
}

\author{
Imran Hussain Khan Suddahazai a,b,1,* \\ ${ }^{a}$ The One Institute Markfield Institute of Higher Education, United Kingdom \\ ${ }^{\mathrm{b}}$ University of Gloucester, United Kingdom \\ 1 ihk@suddahazai.org * \\ * corresponding author
}

ARTICLE INFO

Received 2020-04-28

Revised 2020-07-21

Accepted 2021-04-29

Published 2021-04-30

Keywords

Leadership

Islamic education

Empirical inquiry

Religiosity

\section{ABSTRACT}

The research undertaken sought to address a critical vacuity within contemporary Muslim scholarship on 'educational leadership. The empirical investigation explored the relationship between the formation of 'Religiosity' and the styles of 'Educational Leadership' as experienced by graduates of Muslim Institutes of Higher Education in the UK (MIHEUK). The study was conducted via a single case design with embedded units of analysis. The instruments utilized for data collection were the Muslim Subjectivity Interview Schedule (MSIS), SemiStructured Interviews (SSI), and Focus Group Discussions (FGD). The data was analyzed to deduce the participants' mode of subjectivity by adopting an established criterion developed by Sahin. The study concluded that the educational leadership' styles of Muslim educators working within traditional and hybrid MIHEUK influenced modes of 'religiosity' and 'subjectivity' of Muslim students.

This is an open access article under the CC-BY-SA license.

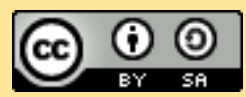

\section{Introduction}

This paper exploring the relationship between the 'formation of religiosity and the styles of educational leadership experienced by contemporary graduates of Muslim Institutes of Higher Education in the UK (MIHEUK). The general conclusion derived from a comprehensive review of the literature on educational leadership within Muslim contexts revealed a dearth in contemporary research. Although several prominent reports [1], [2] had initiated an exploration into the impact of Muslim educational issues in the UK, they were rather broad and outdated. The burgeoning body of research influenced by the 'Islamization of Knowledge (IoK) movement has begun to explore the notion of leadership from an Islamic perspective, but this is currently at a nascent stage with regards to its conceptual maturity and genuine potential to contribute to the field [3]-[7]. Consequently, an underlining aim of the research process was to formulate a self-reflective critical dialogue and critique of the contemporary understanding and practice of educational leadership by Muslim educators. Even a minimalist reading of the Muslim tradition revealed unprecedented homage and obeisance to the notion of the teacher leader. The onus was on learning to appreciate and recognize the antecedents responsible for shaping Muslim educators' pedagogical practice and styles within MIHEUK. The Muslim leader should attribute any successes to God and comply with a code of fairness in relations with his subordinates, forgiving them to the extent that this is in his power, encouraging others to be tolerant, and discussing and sharing things with them [8]. 
The study in seeking to explore the relationship between the formation of religiosity and the styles of educational leadership postulated the following questions: 1) what is the Muslim graduate experience of 'educational leadership' at Muslim Institutes of Higher Education in the UK?; 2) how is 'educational leadership' defined and understood in the classical Islamic and contemporary perspectives?; and 3) what is the impact of educational leadership styles on the formation of religiosity in Muslim graduate students? To address these questions, the study adopted an 'exploratory empirical qualitative case study' method centered within an 'interpretive- ethnographic' approach. The exploratory aspect of the study implied that the approach undertaken at the start would be broad, open and receptive to new information and insights, but with time the focus would become sharper and the area of concentration narrower [9]. The exploratory method comprises several data collection methods to investigate the phenomenon under study. This entails the undertaking of a thorough review of literature, the conduct of interviews, as individual semi-structured and group orientated focus group arrangements, alongside documentary analysis.

The review of literature explored the theoretical definitions of leadership from a classical and contemporary perspective via a 'critical-comparative' approach, which employed an educational hermeneutical strategy. This implied that religious texts, such as the Quran, hadith literature and the classical texts from the Islamic tradition were critically analyzed with consideration to historical and contemporary contexts. Educational hermeneutical approach was utilized to derive an understanding of leadership through a linguistic exploration of key educational concepts from the Quran [10]. The early work undertaken by scholars from the classical era was identified and utilized to gain an appreciation for the very foundations that give meaning to the Islamic educational ideal. Postulates that although the core Islamic concepts are universal, their application is dependent upon the context and situation [11]. Therefore, the definitive hermeneutical understanding of the educational, pedagogical and leadership principles, as derived from the Islamic tradition, allows for the formulation of contemporary educational concepts.

\section{Method}

The empirical investigation was conducted via a single case design with embedded subunits of analysis. The 'case study' subunits comprised of five individual interviews and three focus groups encased as single 'case studies' or units of analysis. The Semi-Structured Interviews (SSI) were utilized to identify the characteristics and styles of leadership as experienced by the students. These descriptive accounts were then contrasted and evaluated against contemporary models of 'educational leadership'. This dialogical methodological process sought to explore the possible relationship between 'educational leadership' styles and the development of a participant's worldview or 'mode of religiosity'. There were also three focus groups held in various geographical parts of the UK categorized as: North, Midlands and South. The subjects were selected based on their current or past enrolment in the last five years at an MIHEUK. As the principle subjects of the fieldwork research were graduate students of MIHEUK, they comprised the sample from which the data was gathered.

An additional data collection, documentary analysis consisted of collating key administrative and managerial documentation available on the specific MIHEUK. This included reviewing and analyzing available curriculums, course outlines, suggested reading lists, past exam papers and exemplar papers available from their libraries and academic staff. The instrument utilized to decipher the 'religiosity' or personal attitude of students towards the 'belief in' and 'practice of' a specific faith system alongside the level to which this has been informed by critical or reflective practices, the 'subjectivity', was Sahin's Muslim Subjectivity Interview Schedule (MSIS). The adoption of this methodological tool allowed for an in-depth examination into the development of an individual's psychosocial personality. The data was analyzed to deduce the mode of subjectivity for the participants by adopting the criteria for analyzing the participant's mode of religiosity. This is an established criterion as developed by Sahin [12] based upon Marcia's earlier framework on the 'identity status' model [11].

\subsection{Muslim Subjectivity Interview Schedule (MSIS)}

To garner an empirical appreciation of the selected participants "religiosity" and "subjectivity" the first instrument to be utilized is Sahin's Muslim Subjectivity Interview Schedule (MSIS) [11]. Measure of religiosity according to Sahin implies the deciphering of personal attitudes towards the 'belief in' and 'practice of' a specific faith system. The level to which this has been informed by critical or reflective practices is entailed in the notion of 'subjectivity'. Sahin perceives this to be the constant dialogical process that construes the self through a personal narrative, which means "we 
continuously reinterpret our sense of self according to our changing life conditions" [13]. Therefore, the literature supports Sahin's work on 'identity formation' as it also conceives both the self (nafs) and faith (iman) as psychosocial constructs [14].

The adoption of this methodological tool allowed for an in-depth examination into the development of an individuals' psychosocial personality. The soft qualitative data provided a body of evidence that allowed for determining the subjectivity of the individuals, which could be compared to the styles of educational leadership the students had encountered. Hence, there were no preconceived notions of existing leadership styles or types of religiosity but only those that were extracted from the interview process. Although the MSIS is composed of a trilateral empirical strategy to gather and assess data in order to measure the subject's religiosity, for the purposes of this study the primary tool used was the semi-structured interview (SSI), which was subsequently bolstered and supported by the original two components, the Sahin-Francis Questionnaire [15] and Self- Characterization Sketch.

\subsection{Sahin-Francis Attitude Questionnaire}

The Sahin Francis attitude Questionnaire, derived from Leslie J. Francis' work on quantifying an individual's attitude towards religion, was utilized to collate data on a subject's attitude towards Islam. The questionnaire referred to as 'You and Your Faith' consisted of 23 questions rated on a five-point Likert scale (agree, strongly agree, not certain, disagree, disagree strongly). Although this was an extremely insightful tool for explorations into a specialized study on Muslim identity formation, this 'quantitative' method was only utilized as a supporting reference mechanism to inform the data analysis process. The participant subjects, in being selected, had already demonstrated a high commitment to the Islamic faith. Thus, in the first instance, the criteria for the sample entailed professing the Islamic faith, had or currently were attending an MIHEUK to study an Islamic science and were working or looking for work within an Islamic educational institute. The second aspect of the attitude to Islam encompassed the 'Self-Characterization Sketch' (SCS) based upon Kelly's Personal Construct Theory (PCT) [16]. This allowed the researcher to understand the subject's life-view and development of their faith from their own perspective.

\subsection{Measuring Modes of Islamic Religiosity and Subjectivity}

The final part of the multifaceted MSIS comprised of an SSI that acted as a valuable tool to create and support the phenomenological framework for this study. The current format of the MSIS was based upon Marcia's 'identity status' model [17], which itself was derived from Erikson's framework on 'epigenetic' identity development in the human lifecycle. Marcia introduced a four-fold typology that aims to explore the processes of 'commitment' and 'exploration' and appropriate a mode of religious subjectivity [18]. The four- fold typology is summarized in Table 1.

Table 1. Marcia's Modes of Religious Subjectivity

\begin{tabular}{ccc}
\hline & Commitment & No Commitment \\
\hline Exploration & Achieved & Moratorium (Exploratory) \\
No Exploration & Foreclosed & Diffusion \\
\hline
\end{tabular}

Marcia's work was structured around establishing an identity "that is conceptualized as a stage of ego growth in late adolescence" [19] and is not separate from the experiences of the individual. Although identity is noted to be an on-going process, the researcher was able to assess and apply Marcia's four identity statuses in order to better understand the subjects interviewed and apply the theoretical implications of a specific internal structure. Therefore, each mode must be identified as a possible life-view built on religiosity that identifies the subject's religious journey thus far with a comparison to their understanding and experience of leadership [11]. In relation to this study, the principal aim was to determine the participants religiosity by discerning the 'exploration' and 'commitment' demonstrated through answers relating to the foundational comprehension of the fundamental components of the Islamic faith: Belief (i'tiqad), Acts of worship (ibadat), Social Responsibility (mu'amalat) and Morality/ Ethics (akhlaq). The interview attempted to understand if their personal perspectives on the fundamental Islamic tenets had been developed through an informed 'exploratory' process or distinguished by its dearth in 'exploration' and thus 'foreclosed'. These modes of subjectivity essentially provide a reference as Erikson had postulated to the observance of a unique identity that had been developed as a result of the participants' educational experience and 
environment [20]. This implied that religious commitment informed by exploration, indicated the 'achieved' mode of religiosity, whereby exploration without religious commitment was designated the 'moratorium' mode of religiosity. However, 'commitment' that lacked exploration was deemed to be the 'foreclosed' mode of religiosity, whilst a complete absence of 'commitment' and 'exploration' signified the 'diffused' mode of religiosity (see Table 2).

Table 2. Sahin-Marcia Modes of Establishing Religious Commitment

\begin{tabular}{ccccc}
\hline & Diffused & Foreclosed & Moratorium & Achieved \\
\hline Commitment & Low & High & Low & High (relatively) \\
Exploration & Low & Low & High & High \\
\hline
\end{tabular}

\subsection{Analysing Data}

The study utilized Yin's recommendations of adopting existing theories and literature to formulate the research objectives, the theoretical propositions, organization and conduct of the data analysis phase [21]. hence, the central components of the research such as themes and issues were identified through the literature and contrasted with the empirical findings. A deductive approach utilized a modified "three-stage data analysis" procedure that was originally derived from Saunders [9]. The themes derived from the review of literature and preliminary research are encapsulated in Table 3.

Table 3. Standard Interview Themes

\begin{tabular}{cc}
\hline \multicolumn{1}{c}{ Theme } & Purpose \\
\hline $\begin{array}{c}\text { Defining and understanding the concept of } \\
\text { leadership }\end{array}$ & $\begin{array}{c}\text { To establish the subject's understanding of leadership and explore } \\
\text { leadership in an Islamic context }\end{array}$ \\
$\begin{array}{c}\text { Describing experience of 'educational } \\
\text { leadership' at MIHEUK }\end{array}$ & $\begin{array}{c}\text { To establish the type of leadership experienced and understand its } \\
\text { effects on students, learning and self- development. }\end{array}$ \\
$\begin{array}{c}\text { Provisions or courses specifically aimed at } \\
\text { developing leadership in students at } \\
\text { MIHEUK (Approach towards self and } \\
\text { professional development) }\end{array}$ & $\begin{array}{c}\text { To establish which current provisions are favoured by MIHEUK and } \\
\text { assess their effectiveness. Furthermore, to establish how the students } \\
\text { were motivated by the MIHEUK to enhance their own understanding } \\
\text { and develop their unique characteristics. }\end{array}$ \\
$\begin{array}{c}\text { Development of educational leadership } \\
\text { capability }\end{array}$ & $\begin{array}{r}\text { To assess if subjects felt prepared by their MIHEUK to take on } \\
\text { leadership roles in their job and private affairs. }\end{array}$
\end{tabular}

\subsection{Data Analysis}

1) Modes of Religious Subjectivity

The study sample consisted of five individual case studies and three focus groups with ten participants per group. The case study participants were assessed for their Commitment and mode of Subjectivity with commitment being evaluated with respect to the participants' adherence to the orthodox Islamic beliefs and practices. Due to the lengthy process of the religiosity element of the MSIS, the FG participants were requested to simply complete the questionnaire on the commitment and attitude towards Islamic practices and beliefs. Table 4 summarizes the results of the MSIS of the individual participants.

Table 4. Individual MSIS and Semi-Structured Interviews

\begin{tabular}{ccc}
\hline Name of Participant & Age & Mode of Subjectivity \\
\hline Tufail & 29 & Foreclosed \\
Hassan & 26 & Foreclosed \\
Samira & 27 & Exploratory- Achieved \\
Farzana & 34 & Exploratory- Moratorium \\
Nazia & 28 & Exploratory-Achieved
\end{tabular}

2) Exploring Leadership Styles and Models

The data gathered through the dialogical interview process sought to capture the participants' worldview and a narrative of their experience of 'educational leadership' at their respective MIHEUK. This was attained through an exploratory use of the SSI, whereby the focus was not to fixate upon 
predefined questions but work within an identified theme, through open dialogue. Conversely, due to the embryonic state of contemporary Islamic scholarship, there exist no uniquely identifiable and innovative criteria for evaluating and identifying 'educational leadership' models and styles in Muslim Institutes. Therefore, the study identified the most common models and styles of educational leadership in modern scholarship and utilized them as references for possible similarities and contrasts based upon the participants' description of role, behavior, attitude, and personality of their own educators. The data gathered through the SSI revealed three styles of leadership, which the study has uniquely classified in Table 5.

Table 5. Styles of Leadership

Educational Leadership Style

The Gatekeeper

The Conductor

The Cultivator

\section{Characteristics}

These leaders both act and are accepted to be the 'Gatekeepers' to the tradition.

These leaders are charismatic but possess authoritarian command over their followers with little deviation from set instructions. They also establish rules and regulations for followers. Students of these educational leaders tend to demonstrate a generally foreclosed mode of religiosity and subjectivity, which is also apparent from their modus operandi.

This type of leader reflects the instructional and transactional mode of leadership, as their approach is more akin to managerial tasks with little vested interest in the development of the students. Their task is to deliver the set curriculum and ensure all set requirements are fulfilled. As above their students generally demonstrate foreclosed modes of religiosity and subjectivity, which is also discernible from their educational teaching practices.

This type of leader reflects the transformational mode of leadership as they seek to aid the students in developing their own abilities to reflect, analyse, make decisions and take responsibilities for their actions. Students and leaders are characterised by achieved and moratorium modes of religiosity and subjectivity.

\section{Results and Discussion}

This research demonstrates that there are two very distinct types of MIHEUK, each with a specific focus and rationale for their existence; the traditional Muslim seminaries and the new contemporary hybrid educational institutes based upon the secular university models.

\subsection{Religiosity}

The Sahin Francis (MSIS) was utilized to ascertain the impact of 'educational leadership' models within MIHEUK on the development of a particular mode of religiosity and subjectivity of their graduate students. The MSIS proved to be an effective tool as it sought to measure subjective attitudes that were either formed as a result of 'self-exploration' (exploratory mode) or inherited as a set of axiomatic truths from cultural, family or educational influences (foreclosed). However, in analyzing the gathered data the study found subjectivity to be context dependent. Participant may appear to demonstrate a particular mode of subjectivity with regards to religion for example but may display a completely different mode of subjectivity with regards to another topic. The analysis of the MSIS of the two participants (Hassan and Tufail) deemed them to be foreclosed. The participants equated the notion of questioning and critically analyzing the Islamic tradition as being tantamount to sacrilegious and irreverent practice. However, in discussing the development of their institutes, social and political issues not connected to the Islamic tradition they demonstrated the ability for an exploratory mode of subjectivity. In Samira's example it has been identified that she has an exploratory mode of religiosity, yet she refuses to completely have ever attempted to reject the entire notion of faith. According to the strictest adherence to the criteria she may be considered foreclosed but her ability to consistently learn and question her existing understanding also implies that she is willing to explore and question the tradition. Furthermore, this attitude was not developed through the leadership styles of her educators but through her professional experience.

In the case study of Farzana deemed to be 'exploratory' albeit moratorium, it was her refusal to follow the teaching career and her non-commitment to the practice of her faith, based upon rationalistic and logical deductions that implied an exploratory mode. Another reading of the MSIS could argue that Farzana demonstrates shades of foreclosure as she never critiqued the theology of the Ismailia faith and undertook the post-graduate program with full knowledge of its Ismailia bias. The institute requires of its students to declare their loyalty and adherence solely to the Ismailia path. Also, in analyzing Nazia with a 'exploratory diffused' mode of religiosity it is possible to suggest that her 
initial secular higher educational experience had already introduced her to the contemporary tools deemed to be essential for modes of exploration. However, her failure to directly challenge her personal understanding of the Islamic tradition other than to suggest that existing tradition must be reformulated can be considered as a 'foreclosed' perspective. Therefore, in reflecting upon the findings of this study it can be stated that the empirical aspect of this research has merely taken a snapshot of each individual participants experience at the time. To contextualize for this finding, it must be remembered that the study defines the notions of identity and subjectivity, as the composite of an individual's personal and social beliefs, values and role that are affected by both internal and external factors [11], [22], [23].

The Islamic concept of identity, encapsulated in the notion of the self (nafs) or personality, provides the reference point for the intrinsic knower that interacts with its environment through interpreting the social and environmental stimuli. Hence, the formation of Personality and subjectivity formulates a recursive lifelong process. With specific regards to faith and religion none of the individual and FG participants criticized their educators' knowledge, accuracy and veracity of the Islamic tradition. The liberal secular educationalists vehemently question the credibility of Islamic virtues as "unprovable propositions" that cannot be critically scrutinized, which implies that students schooled in a particular set of beliefs are "not educated but indoctrinated". Barrow and Cook identifies the notion of indoctrination to entail a complete absence of critical analytical thinking thus, leading to autocratic modes of education [24], [25]. Critics cite the blind adherence to a fixed ideology that claims to the absolute truth as dogmatic and intolerant. For example, Halstead argues that "Independence of thought and personal autonomy do not enter into the Muslim thinking about education, which is more concerned with the progressive initiation of pupils into the received truths of the faith [26]. Although a great body of Muslim literature is dedicated towards refuting and countering these accusations, some Muslim thinkers accept and acknowledge this criticism. They attribute the blind imitation (taqlid) to have systematically destroyed the Muslim educational system before the advent of colonial and secularist policies. Sardar observes that the Muslim has been reduced to the role of a passive follower with no opportunity to actively engage with the tradition and "participate in its contemporary formation and expression" [27].

\subsection{Educational Leadership Styles}

It is postulated from the unique data captured in the findings of the empirical case study, that the style of leadership experienced by the participants appears to merely reinforce a certain tradition and accepted practice of the Islamic tradition they are familiar with. The study suggests that traditional seminaries embody an apprentice-style leadership model, whereby development of students is reliant entirely on the teachers, who represent a particularly defined tradition, or a mythological ideal that is continually reinforced through the curriculum. Thus, it can be argued, that the religiosity of students is 'foreclosed' as they become tools for propagating the tradition through imitation and regurgitation of the established and accepted facts and information. This empirical study provides an initial reference to the significant contribution of educators at MIHEUK in formulating their student's current understanding of the Islamic worldview. This study's participants declared the educational leadership style of their teachers to be 'influential' and 'inspirational' alluding to a contrast with the Charismatic style of leadership. However, these descriptions cannot be adjudged to be in line with Burns formulations on the Inspirational aspect of Transformational leadership, as the educator only served to reinforce previously held convictions [28]. This is further evident in that students are keen to attribute their personal comprehension of the Islamic faith to being directly informed by their teacher's character and instructions. This can be perceived in the student's infatuation and reverence for their educators' personality and apparent knowledge base. Furthermore, the educational cultures of the Institutes appear to encourage the acceptance that the teachers constitute the prophetic ideal and are beyond analysis or reproach.

The 'Gatekeeper' style of leadership, characterized by its authoritarian nature, was identified by one individual participant (foreclosed mode) and by all three of the focus groups. This style of leadership can be appreciated through a brief analysis of Weber's [29] tripartite model of authority [30], [31]. It is suggested that the Weberian lens provides a unique modular perspective into the development of the 'Gatekeeper' style of leadership in the Islamic tradition. In the Weberian thesis, Prophet Muhammad epitomises the incipient status of the charismatic authority. This antiinstitutional style of leadership seeks to challenge and reformulate the accepted status quo of social norms, normative traditions, and traditional structure of authority. Due to the individual's association with divinity the charismatic leader becomes synonymous with the ideal of reform and purification 
(Tajdid and Islah) of society. The successors to the charismatic leader merely become inheritors of the tradition and the charisma of the leader becomes hereditary or routinised. This leads to the emergence of a second type of leadership model, that of tradition. Weber argued that the "sacredness of tradition" formulates the most original and universal concept of "authority" [29]. From an Islamic perspective, Takim cites the unanimous acceptance (Sunni tradition) of the Rashidun Caliphs (622$661 \mathrm{AD})$, the Umayyad's (661-750) and the reign of the Abbasid caliph al-Ma'mun (833) as the period of this routinised charisma (traditional authority) [30]. Whereas the Charismatic transition to the traditional model is characterized by the death of the Prophet (s), the transition from the traditional to the rational-legal is marked by the death of reason in the Islamic tradition.

Therefore, the historical demise and the contemporary nadir of the Islamic civilization are marked by the third stage of the Weberian model, the rational-legal authority. Authority has shifted from the living tradition, the dynamic Sunnah, to a residual, stagnant, historical tradition. This entails complete adherence to a set of societal norms that have been canonized as divine juristic laws, the Sharia. Accordingly, the first challenge of Muslim studies into education and leadership must recognize that the rational-legal authority implies a certain mindset, whereby education is perceived to be a risk/reward task. The educators will either be completely authoritarian or follow a transactional style of leadership where they act to merely indoctrinate the student with the requisite information. Hence, the participants equate the notion of questioning and critically analyzing the Islamic tradition as being tantamount to sacrilegious and irreverent practice. This is clearly demonstrated in the refusal of the students to critique the traditional Dars-I Nizami curriculum and the pedagogical styles of their educators. A possible reason for the development of this attitude could be attributed to the rationallegal authority structures of traditional Islamic Institutes or Dar Al- 'Ulums. Due to the influence of the Indian subcontinental community in the UK, these institutes are perceived to be the authentic transmitter of Islamic education with the Deobandi affiliated institutes being the most established and attended. Therefore, they are highly influential in contributing towards the development of Muslim faith leaders within Muslim educational institutes. Therefore, participants deemed to be 'foreclosed' described their educational experience, perspectives on leadership and self-development in juristic, as opposed to educational, terms. They described the purpose of education to be centered upon following the Quran and Sunnah and learning the Sharia. Additionally, they perceived their eventual responsibilities to encompass the upholding of legislative norms encapsulated in such terms as figh, usual, and akham.

The literature findings are thus confirmed to an extent by the empirical research, as the educators from traditional institutes are actively discouraged from seeking to explore and question the sacred Islamic doctrines, as the notion of critical thinking, exemplified by the foreclosed participants, is deemed antithetical to the Islamic tradition. Hence participants identified their personal course supervisors and teachers to be their leaders and sought to aggrandize the role of their teachers. More so, they refused to critique their teacher-leader's behaviors or actions due to what they perceived as their moral, ethical responsibility and loyalty due to their teachers in line with the Sunnah of the Prophet (s). The 'Conductor' style of leadership, which can be understood to be subordinated to the 'Gatekeeper' style of leadership merely seeks to continue propagating the rational-legal heritage as they are tasked. This style of leadership can be compared to the secular Instructional and managerial approach and is characterized by the impersonal and diffident nature of their educators towards their students. Two individual participants and one focus group identified this style of leadership. Although case study Hassan, generally praised his educators he failed to describe any defining characteristics and was generally reluctant to evaluate their conduct and practice. The research findings also revealed that the 'Conductor' educational leadership style also forced some students, especially female students, to develop an exploratory mode of subjectivity.

Samira along with a significant number of the female focus group participants felt as if their educators ignored them. Although they respected the segregation of genders in society, they had little interaction with their educators and thus, formed their conceptions of Islamic education as a result of their professional careers, either as teachers or going onto further study at secular British Universities. Their experience of the traditional Muslim institute raises questions about the general lack of apathy and interest in the female students and the overt sense of gender bias at MIHEUK. Some female students received little direct contact with their teachers and generally felt neglected and ignored with absolutely no avenue for engagement with the institute or its student body. The female students experience of 'educational leadership' effectively entailed an authoritative figure delivering a set educational curriculum, akin to the transactional (managerial) style and model of leadership. This implies that the educator is merely ensuring that the student completes the set curricular requirements 
(transactional) without much concern or consideration for their needs, requirements or welfare. Therefore, female students overtly cite their professional career experience in an Islamic school environment to be responsible for their personal and professional development as opposed to the educators at their MIHEUK. Thus, they reflect upon and critique the traditional Islamic educational system as being dominated by individual personalities that prevent the development of core intellectual skills and abilities. This also highlights the delicate and intricate nature of the MSIS process, as Samira's perspectives on the Islamic tradition can be considered rather staunch and in line with the populist orthodox Sunni promulgations.

However, it could be postulated that although the power-based educational leadership styles create resentment, it also enables students to reflect upon their experience. Students, in citing their professional teaching experience, readily admit to reformulating their views on the Islamic tradition due to their experiential knowledge. Thus, it suggested that aloof and negligent styles of leadership could also positively affect the formation of an exploratory mode of religiosity. The 'Cultivator' style of leadership is based upon the notion that educational leadership styles that seek to cultivate in their students the notion of reflection as a guarding against the uncritical, unquestioning attitude of following the routine is inherently connected to the Islamic ideal [32]. The case study participants demonstrating an 'exploratory' mode of religious subjectivity identified the notions of 'critical thinking', 'questioning', 'reflection' and 'pedagogy' as significant factors in their educational experience. Although it can be suggested that the participants initiated their post-graduate studies with relatively exploratory minds, as they had completed undergraduate degrees from secular mainstream British Universities. Therefore, they were already aware of the contemporary social scientific methods and their application to Islamic thought. However, this only served to cause significant doubts in the Orthodox Islamic tradition as it was practiced and understood by their communities. However, the case-based learning approach adopted by their educators introduced the notions of critical thinking and questioning through active classroom sessions. Topics were contextualized and discussed in line with familiar contemporary situations. The students' intellectual development was 'scaffolded' as senior and advanced students acted as aids and assistants to their teachers during lessons, which served to enhance their own learning abilities and practical experience. This student orientated pedagogical approach implies that the teachers act in accordance to the Sunnah of Prophet Muhammad (s) as role models for their students. Thus the 'Cultivator' style of educational leadership adheres to Nodding's notion of ethical caring as the educators demonstrate a moral and ethical responsibility towards their students, as the 'educator' (one-caring) 'receive' the student (cared for) into 'themselves' by being completely devoted to the students' requirements [33].

This ethical caring approach ensures that teachers take moral responsibility for the development for their students. The role model-status of the teacher encapsulates a complete behavioral pattern both in personal and public life. In the case of participant Nazia, her academic study at the undergraduate level dehumanized the notion of faith and impersonalized her connection with Islam as it was presented as a historic tradition to be looked back upon [33]-[35]. Thus, her teachers' ability to reconcile the scientific study of the faith with its dynamic, spiritual, ethical and moral ethos as a living tradition designates her teacher as having transformed her perspective and understanding. In the case of Farzana, the Ismailia participant, she accredits her educators balanced and accommodating characteristics to her skeptical approach to religion. Although he sought to counsel and inform her to the essentials of the Ismailia faith, she never felt pressured into accepting the ritualistic aspects of the faith. Furthermore, he accepted her refusal to follow the Ismailia teaching career as designated by her postgraduate Masters' program.

Therefore, the participants attribute their personal understanding of the faith to their teachers, whom they regard to be demonstrating the 'Cultivator' style of leadership. This style of leadership acts in contradistinction to the teacher imposing his/her own perspective on the students (Gatekeeper); simply just trying to make sure the student completes the set curricular requirements (Conductor); the student is simply being enamored or attracted to the teacher's personality due to the teacher's mannerisms, speech or reputation (Charismatic). This style of leadership can be compared to the popular transformational model as the leader gains the trust of his/her students by inspiring them to become more creative and grow as individuals. A crucial defining aspect between the 'Cultivator' and the 'Transformational' models is, with regards to the source of their Trust, Inspiration, Creativity and Personal Growth (components of Transformational Leadership). Whereas the 'transformational' style of leadership is derived from secular literature the 'Cultivator' style of leadership is cemented in the notion of tawhid and knowledge as derived from the Islamic worldview. 
Educational leadership models were examined through a combination of informal discussions and visitations to MIHEUK in addition to the empirical case studies and the review of literature. These findings were then contrasted to the contemporary secular research into leadership alongside the classical Islamic traditional and theological narratives. These findings then allowed the study to explore the impact of current practices and embodiment of educational leadership by Muslim educators upon the formation of religiosity in Muslim graduate students and the influence it has had on their personal leadership competency. Data gathered from the empirical field study revealed that participants attending traditional MIHE demonstrated 'foreclosed modes of religious subjectivity' and identified two styles of 'educational leadership' at these institutes, the 'Gatekeeper' and the 'Conductor'. Participants attending the new hybrid MIHE demonstrated 'exploratory' modes of religious subjectivity and identified their educators to have exhibited the 'Cultivator' style of leadership. The review of literature alongside the empirical study uncovered issues that, although beyond the remit of this exploration, provide fantastic insight into the Muslim community in the UK. Most Muslims encountered throughout the research process articulated grave reservations about living in a secular society. The primary fears they shared were centered upon the issues of immorality, godlessness, and political conflicts with Muslim-majority nations. They also cited the increased cases of Islamophobia, anti-Islamic/Muslim bigotry in the mass media and the formulation of hostile policies by governmental bodies and security services as sound evidence of an anti-Islamic/ Muslim conspiracy. Whilst the research gathered through the literature, interviews, visits, informal discussions, meetings, conferences, and Muslim media suggested that the accusations levied at the secular west are credible, yet they do not address nor explain the 'dilemma of the Muslim Ummah'.

\section{Conclusion}

Muslim educators working within both the traditional and new MIHEUK, alongside recent graduate students at these institutes, have begun to recognize that the notion of Islamic Education must be revisited and reformulated to survive the Muslims as a people within the western context. The literature is replete with major criticisms of Islamic educational institutes regarding their curricula, instructional methods, and environment. The empirical case study participants who attended traditional MIHEUK possessed no definable skills and abilities that they could employ to earn a living other than teaching a set curriculum within a traditional Muslim seminary. With an increasing number of Muslim students graduating from MIHEUK, the career opportunities and remunerations are extremely unappealing and unattractive. Graduates are often left to work as taxi drivers, waiters, delivery drivers, or part-time masajid teachers before they can re-train to gain employable skills and qualifications. Therefore, a significant end goal for this study is to present Muslim educators and students with the findings and possible consequences for the uptake of Islamic education soon.

\section{Acknowledgment}

The authors would like to thank the The One Institute Markfield Institute of Higher Education, United Kingdom, for granted supports. Furthermore, thanks to all who participated for their participation in this study.

Author contribution

Funding statement

Conflict of interest

Additional information

\section{Declarations}

: IHKS: Conceptualization, methodology, writing, reviewing, and editing.

: No funding was made available for this research.

: The authors declare no conflict of interest.

: No additional information is available for this paper.

\section{References}

[1] M. Mukadam, A. Scott-Baumann, A. Chowdhary, and S. Contractor, "The training and development of Muslim Faith Leaders Current practice and future possibilities," 2010, available at: Google Scholar.

[2] A. A. El-Affendi, Contextualising Islam in Britain: exploratory perspectives. Centre of Islamic Studies, 2009, available at: Google Scholar. 
[3] M. T. A. Lopes Cardozo and R. Shah, "A conceptual framework to analyse the multiscalar politics of education for sustainable peacebuilding," Comp. Educ., vol. 52, no. 4, pp. 516-537, 2016, doi: 10.1080/03050068.2016.1220144.

[4] D. M. M. Zin, S. Mohamed, M. I. A. M. Kashim, E. A. Jamsari, A. F. Kamaruzaman, and Z. A. Rahman, "Teachers' knowledge and practice in implementing the thematic approach in pre-school," Int. J. Civ. Eng. Technol., 2019, available at: Google Scholar.

[5] I. H. K. Suddahazai, "The development of leadership through islamic education," 2015, available at: Google Scholar.

[6] S.-L. Ang and K. C. P. Low, "Islamic leadership lessons from the 9th century based on Ibn Khaldun's MUQADDIMAH,” J. Educ. Res., vol. 3, no. 3, pp. 212-219, 2012, available at: Google Scholar.

[7] A. R. Moten, "Leadership in the West and the Islamic world: A comparative analysis," World Appl. Sci. J., vol. 15, no. 3, pp. 339-349, 2011, available at: Google Scholar.

[8] K. Arar and K. Haj-Yehia, "Perceptions of educational leadership in medieval Islamic thought: a contribution to multicultural contexts," J. Educ. Adm. Hist., vol. 50, no. 2, pp. 69-81, Apr. 2018, doi: 10.1080/00220620.2017.1413341.

[9] M. Saunders, P. Lewis, and A. Thornhill, Research methods for business students. Pearson education, 2009, available at: Google Scholar.

[10] A. Sahin, "Critical issues in Islamic education studies: Rethinking Islamic and Western liberal secular values of education," Religions, vol. 9, no. 11, p. 335, 2018, doi: 10.3390/re19110335.

[11] A. Sahin, New directions in Islamic education: Pedagogy and identity formation. Kube Publishing Ltd, 2013, available at: Google Scholar.

[12] A. Sahin, "Critical Issues in Islamic Education Studies: Rethinking Islamic and Western Liberal Secular," Religions, vol. 335, no. 9, pp. 1-29, 2018, doi: 10.3390/rel9110335.

[13] A. Sahin, "Critical/dialogic Islamic education: attitudes towards Islam and modes of religious subjectivity among British Muslim youth.” The University of Birmingham, 2002, available at: Google Scholar.

[14] A. Sahin and L. J. Francis, "Assessing attitude toward Islam among Muslim adolescents: The psychometric properties of the Sahin-Francis scale," Muslim Educ. Q., vol. 19, no. 4, pp. 35-47, 2002, doi: 10.1037/t18899-000.

[15] L. J. Francis, A. Sahin, and F. Al-Failakawi, "Psychometric properties of two Islamic measures among young adults in Kuwait: the Sahin-Francis Scale of Attitude toward Islam and the Sahin Index of Islamic Moral Values," J. Muslim Ment. Health, vol. 3, no. 1, pp. 9-24, 2008, doi: 10.1080/15564900802035201.

[16] G. Kelly, The psychology of personal constructs. Routledge, 2020, doi: 10.4324/9780203359037.

[17] J. Kroger and J. E. Marcia, "The identity statuses: Origins, meanings, and interpretations," in Handbook of identity theory and research, Springer, 2011, pp. 31-53, doi: 10.1007/978-1-4419-7988-9_2.

[18] J. E. Marcia, "Development and validation of ego-identity status.," J. Pers. Soc. Psychol., vol. 3, no. 5, p. 551, 1966, doi: 10.1037/h0023281.

[19] D. Bilsker and J. E. Marcia, “Adaptive regression and ego identity,” J. Adolesc., vol. 14, no. 1, pp. 7584, 1991, doi: 10.1016/0140-1971(91)90046-T.

[20] H. Sackman, W. J. Erikson, and E. E. Grant, "Exploratory experimental studies comparing online and offline programming performance," Commun. ACM, vol. 11, no. 1, pp. 3-11, 1968, doi: $10.1145 / 362851.362858$.

[21] R. K. Yin, "Design and methods," Case study Res., vol. 3, no. 9.2, 2003, available at: Google Scholar.

[22] J. E. Marcia, A. S. Waterman, D. R. Matteson, S. L. Archer, and J. L. Orlofsky, Ego identity: A handbook for psychosocial research. Springer Science \& Business Media, 2012, available at: Google Scholar.

[23] L. M. Joiner, E. L. Erickson, and J. B. Crittenden, "Occupational plans and aspirations of deaf adolescents," JADARA, vol. 2, no. 3, p. 8, 1968, available at: Google Scholar.

[24] R. Barrow, The philosophy of schooling. Routledge, 2015, doi: 10.4324/9781315683577.

[25] K. Cook, Trust in society. Russell Sage Foundation, 2001, available at: Google Scholar. 
[26] J. M. Halstead, “An Islamic concept of education,” Comp. Educ., vol. 40, no. 4, pp. 517-529, Nov. 2004, doi: 10.1080/0305006042000284510.

[27] Z. Sardar, "Why Islam Needs Islamic Science," New Sci., vol. 94, pp. 25-28, 1982, available at: Google Scholar.

[28] J. M. Burns, “Leadership.” New York: Harper \& Row, 1978, available at: Google Scholar.

[29] M. Weber, Basic concepts in sociology. Citadel Press, 1962, available at: Google Scholar.

[30] L. N. Takim, The heirs of the prophet: charisma and religious authority in Shi'ite Islam. SUNY Press, 2012, available at: Google Scholar.

[31] S. H. Nasr, H. Dabashi, and S. V. R. Nasr, Expectation of the Millennium: Shi'ism in History. SUNY Press, 1989, available at: Google Scholar.

[32] K. W. Dewey and R. Zugsmith, "An Experimental Study of Tissue Reactions About Porcelain Roots 1," J. Dent. Res., vol. 13, no. 6, pp. 459-472, 1933, doi: 10.1177/00220345330130060601.

[33] M. Gosper and D. Ifenthaler, Eds., Curriculum Models for the 21st Century. New York, NY: Springer New York, 2014, doi: 10.1007/978-1-4614-7366-4.

[34] T. Lickona, Educating for character: How our schools can teach respect and responsibility. Bantam, 2009, available at: Google Scholar.

[35] L. S. Vygotsky, Mind in society: The development of higher psychological processes. Harvard university press, 1980, doi: 10.2307/j.ctvjf9vz4 